\title{
PHD THESIS SUMMARY: \\ Ethics before God and markets: a theory of moral action in conversation with Adam Smith and Ernst Troeltsch.
}

JOSEPH D. BLOSSER

PhD in religious ethics, June 2011

University of Chicago

The dissertation contends that in our religiously charged and economically unstable world the disciplines of ethics, theology, and economics must be involved in a conversation about human moral action and well-being. We live in a world of increasingly fragmented social spheres and a plurality of values that has seen the conversation between theology and economics become acrimonious or simply non-existent. The dissertation uses the field of ethics to begin a rapprochement between theology and economics by following the deeply interdisciplinary works of Adam Smith and Ernst Troeltsch, who each use the insights of all three fields to build their visions of moral action in the world.

The dissertation develops a view of moral action that helps the conversation between theology and economics avoid two well trod traps: theological reflection on the economy that does not take seriously the real constraints and drives of human behavior and the reduction of theology to economic rational choice without remainder. The thesis of the dissertation is necessarily two-tiered. It first shows the structural similarities in the works of Smith and Troeltsch that enable the construction of a tensive, multidisciplinary view of moral action that arises in the face of history and the divine. Then it argues that such moral action brings theology and economics back into conversation, because it can bridge their divergent views on freedom, through the mediating power of ethical freedom, and it can bridge their divergent views of morality, through the symbol of responsibility. It places a Smithian virtue theory and a Troeltschian theory of compromise within a responsibility ethic to describe the individual quest for personality in a fruitful relationship with God and one's many social spheres.

An adequate ethical response to our world must be a relational one that holds us responsible for forming compromises for how we should 
live out the different values in our moral spheres. We are formed to build such compromises through our sympathy with others, our understanding of history and other peoples, our ethical freedom and imagination, and the virtues that our communities teach. Such compromises disclose-if even only in part-something about real moral values. The lure of God's personality-the unity of value that pervades the diversity of the world-draws us to the hard work of inventing moral compromises in relationship to others, and through such moral labor we form responsible personalities. The responsibility ethic developed in the dissertation offers a way to talk about moral action that is responsive to both theological and economic methods, and it provides a necessary critique of both. It enables us to express what it means to be an ethical personality before God and the market.

Joseph D. Blosser obtained his $\mathrm{PhD}$ from the University of Chicago. His dissertation was supervised by William Schweiker, Edward L. Ryerson distinguished service professor of theological ethics at the University of Chicago; and his two readers were Kathryn Tanner, professor of systematic theology at Yale University, and Deirdre McCloskey, distinguished professor of economics, history, English, and communication at the University of Illinois at Chicago. Dr. Blosser now serves as the Robert G. Culp Jr. director of service learning and assistant professor of religion and philosophy at High Point University in North Carolina. He continues to research at the intersections of ethics, theology, and economics.

Contact e-mail: <Jblosser@highpoint.edu> 